those of the deep Norwegian basin. The river-system is, on the whole, similar to that which now exists, and we may fairly infer that the building of the British Isles was completed. All we can say is, that there must have been good workmen in later Pliocene times; for if these views are correct, considerably more than balf the physical features of the British Isles, both geographical and hydrographical, date from this limited interval of geologic time.

In dealing with the final or Pleistocene stage, its abnormal climate, its submergences, and all the other enigmas of the Great Ice Age, the author avoids the extreme theories which find so much favour in some quarters. He allows that " the uncertainty which exists with regard to the real succession, and to the precise mode of formation of these Glacial deposits, makes it unsafe to attempt a geographical restoration of any of the several phases of the Glacial epoch." $\mathrm{He}$ prefers to select for illustration the period in Pleistocene time when the rigour of the Ice Age had moderated, and when the British region had emerged from the waters of the Glacial Sea. The bed of the German Ocean is now so filled with débris that " the upheaval necessary to convert this sea into land after the Glacial period was 100 fathoms less than would have been required to effect the same result in later Pliocene time." An extension of the Rhine meanders throngh the great plain, to which the rivers of Eastern England are tributary. This represents the epoch when the coast-line of Western Europe coincided with the $80 \mathrm{fm}$. contour. Subsequently the water gains on the land, these low-lying tracts are destroyed, and our narrow seas are being cleaned out. The last great geographical touch was given when the tidal waters, assisted perhaps by depression, eat their way across the low water-shed of two river-valleys which is now marked by the Straits of Dover.

We have followed Mr. Jukes-Browne with much pleasure through this very interesting study in geographical evolution, and can strongly recommend it to the attention of all geologists and physical geographers. In a case of this sort it is far easier to criticize than to construct, and no doubt each specialist could find something to suggest in every stage of the process from the earliest Palæozoics to the latest Pleistocene times. Many points, also, in ancient geographies must for ever remain mere matters of opinion. What is especially to be commended in this book is its freedom from any extravagant ideas: the author has taken for his motto, in medio tutissimus ibis, and in this spirit has acted throughout.-W.H.H.

\title{
CORRESPONDEINCE.
}

\section{NOTE ON A GLACIAL BED IN BEDFORDSHIRE.}

SIR,-The Lower Greensand forms a well-marked escarpment running parallel to that of the Chalk through Bedfordshire, and overlooking the flats consisting of Oxford and possibly Kimeridge Clay. About a mile from Ampthill in the direction of the ruined mansion at Houghton, quite on the edge of the escarpment, and facing the 
north-west, there is a large pit worked for sand and gravel, which has apparently escaped attention, or at least description. The beds are obviously Glacial, and apparently coeval with the Boulder-clay, but the boulders and pebbles are cemented with greensand, and not with clay. The stratification is distorted, and discontinuons. The greatest depth of the section is about 35 feet, and the beds extend further beneath. Beginning from below, the layers are in one part as follows : loam, conglomerate of boulders, clay, conglomerate, sand, pebbles and half-rounded flints, sand, conglomerate, sandy subsoil; the thickness of each layer being three or four feet. The pebbles and fossils are of all ages, but flint, chalk boulders, and hard iron sandstone predominate. There are also fragments of lignite; Ammonites from the Oolite; Granite, and Igneous rocks. It is just possible that the beds have been deposited under the combined action of ice and rivers, but the beds in no way resemble the river-gravels of the Ouse. A layer of sand 3 or 4 feet thick, and about 25 feet in length, is absolutely free from pebbles, and is of a fine white texture, similar to that used for commercial purposes, and quarried from the Lower Greensand in many places. It looks as though it had been pushed or transported bodily, without any disturbance from the Greensand.

The conglomerate is extremely hard, and fractures occur across the contained pebbles like Hertfordshire pudding-stone. A search for flint implements proved, as was expected, futile.

This section thoroughly deserves a visit, and I should be glad to learn the opinion of geologists about its age and probable method of formation.

P.S.-Mr. Cameron, of H.M. Geological Survey, is of opinion that these beds are Middle Glacial.

Marlborotgh College.

A. S. Eve.

DISCOVERY OF A CIRRIPEDE I. CANADIAN PALÆOZOIC ROCKS.

SiR, - I have just received a communication from my friend $\mathrm{Mr}$. Henry M. Ami, M.A., F.G.S., of the Geological Survey of Canada, dated Ottawa, 23rd August, 1888, in which he makes the following interesting announcement in a postscript:-

"Last Saturday afternoon, whilst collecting in the 'Siphonotreta' band [lower part of Utica Formation=Bala Limestone Group, in part] along the Rideau River-near the rifle range-I had the good fortune to come across what appears to be a fossil Cirripede, allied to Turrilepas. The group to which these ancient barnacles belong lies still in much obscurity; Darwin, Woodward, Lindström, Hall, and Clarke have written on them. I think this is the first time we have found any in Canada in Palæozoic rocks."

I have only to add that I expect shortly to receive the specimen from Mr. Ami for description.

66, Edith Road, West Kensington, W.

Arthur H. Foord. 